\title{
The political ecology of 'ethnic' agricultural biodiversity maintenance in Atlantic Nicaragua
}

\author{
Nicholas E. Williams ${ }^{1}$ \\ University of Colorado Boulder, USA
}

\begin{abstract}
Correlations between farmer ethnic identity and the agrobiodiversity they maintain have been identified globally. This has been maintained even as small-scale farmers are increasingly connected to extra-local political economic systems, which are cited as the driver of global agrobiodiversity erosion. Yet, how ethnicity influences the maintenance of biodiverse farming systems is poorly understood. Employing a political ecology framework that integrated qualitative, demographic, and agroecological methods in Caribbean Nicaragua's Pearl Lagoon Basin, this research revealed patterns indicating that farmers who identify with the area's indigenous (Miskito) and afro-descendant (Creole and Garífuna) 'minority' groups tend to maintain more diverse farms than nearby farmers who identify as mestizo , particularly those who are recent migrants to the region. In contrast to previous studies, however, the most connected farmers in the Basin tend to have the highest levels of agrobiodiversity within their farming systems. Qualitative and regression analyses reveal that ethnic patterns in the maintenance of agrobiodiversity are explained in part by the historical farming practices that characterize land use in the Basin and the agroecological knowledge that farmers develop over a lifetime farming in this socio-ecological context. Further, by acknowledging the plastic nature of ethnic identity, this research highlights the importance of ethnic-based land rights in the Nicaragua's South Caribbean Coast Autonomous Region as a critical factor that directly and indirectly influences the ethnic identities of farmers in the Pearl Lagoon Basin and their abilities to participate in agricultural development projects whose extension activities promote agrobiodiversity conservation.
\end{abstract}

Key Words: Agrobiodiversity, ethnicity, land use and land use change, development, Nicaragua, Pearl Lagoon Basin

\section{Résumé}

Les corrélations entre l'identité ethnique des agriculteurs et l'agrobiodiversité qu'ils maintiennent ont été identifiés dans le monde entier. Le lien a été maintenu même que les petits exploitants agricoles sont de plus en plus connectés à des systèmes économiques et politiques extra-locales, qui sont cités en tant que conducteur de l'érosion globale de l'agrobiodiversité. Pourtant, comment l'origine ethnique influe sur le maintien des systèmes agricoles biodiverses est mal comprise. Employant un cadre de l'écologie politique qui intègre des méthodes qualitatives, démographiques et agroécologiques dans le bassin de la lagune de Pearl sur la côte des Caraïbes du Nicaragua, cette recherche a révélé des tendances indiquant que les agriculteurs qui identifient avec les peuples autochtones (Miskito) de la région et afro-descendant (créole et garifuna) des groupes «minoritaires» ont tendance à maintenir plus diverses fermes que les agriculteurs voisins qui identifient comme mestizo , en particulier ceux qui sont les migrants récents dans la région. Contrairement aux études précédentes, cependant, les agriculteurs les plus connectés dans le bassin ont tendance à avoir les plus hauts niveaux de l'agrobiodiversité au sein de leurs systèmes d'exploitation. L'analyse qualitative et régressions statistiques révèlent que les pratiques historiques agricoles qui caractérisent l'utilisation des terres dans le bassin, et la connaissance agroécologique que les agriculteurs développent sur une agriculture à vie dans ce contexte socio-écologique, sont expliquées en partie par l'appartenance ethnique. En outre, en reconnaissant que l'identité ethnique est fluide, je montre l'importance des droits fonciers à base ethnique

\footnotetext{
${ }^{1}$ Dr. N.E. Williams, Postdoctoral Fellow, Environmental Studies Program, University of Colorado, Boulder, CO, USA. Email: nicholas.e.williams "at" colorado.edu. This research would not have been possible without the support of the Fulbright Foundation, Susan Stonich, Casey Walsh, David López-Carr, Andrea Allen, and Daniel Kramer or the help of my field assistants, Adolfo Martinez and Vanny Brown. I would also like to thank Seeta Sistla and the Journal of Political Ecology reviewers for their helpful comments that substantially improved this manuscript.
} 
dans le bassin. Ceux-ci influencent également la capacité des agriculteurs à participer à des projets de développement agricole, dont les activités extension de promouvoir la conservation de l'agrobiodiversité.

Mots clés: agrobiodiversité, l'origine ethnique, l'utilisation des terres, le développement, le Nicaragua, Pearl Basin Lagoon

\section{Resumen}

Las correlaciones entre la identidad étnica de los agricultores y la biodiversidad agrícola que mantienen se han identificado a nivel mundial. Se mantienen estas tendencias, incluso cuando los agricultores de pequeña escala están cada vez más conectados a los sistemas económicos y políticos extra-locales, que se citan como el catalizador de la erosión de la biodiversidad agrícola mundial. Sin embargo, cómo influye la etnicidad el mantenimiento de los sistemas agrícolas biodiversos es poco conocida. El empleo de un marco de ecología política que integra métodos cualitativos, demográficos y agroecológicos en la Cuenca de Laguna de Perlas del Caribe Nicaragua, esta investigación reveló patrones que indican que los agricultores que se identifican con el área indígena (miskito) y afro-descendientes (criollos y garífunas) grupos "minoritarios" tienden a mantener más diversas fincas que los agricultores cercanos que se identifican como mestizo s, especialmente aquellos que son inmigrantes recientes en la región. En contraste con estudios previos, sin embargo, los agricultores más conectados en la cuenca tienden a tener niveles más altos de biodiversidad agrícola dentro de sus sistemas de cultivo. Cualitativa y análisis de regresión revelan que los patrones étnicos en el mantenimiento de la biodiversidad agrícola se explican en parte por las prácticas agrícolas históricos que caracterizan el uso del suelo en la cuenca y el conocimiento agroecológico que los agricultores se desarrollan durante un cultivo de toda la vida en este contexto socio-ecológica. Además, mediante el reconocimiento de la naturaleza plástica de la identidad étnica, esta investigación pone de relieve la importancia de los derechos de base étnica de la tierra la Región Autónoma Caribe Sur de Nicaragua como un factor fundamental que influye directa e indirectamente las identidades étnicas de los agricultores en la cuenca de Laguna de Perlas y su capacidad de participación en proyectos de desarrollo agrícola, cuyas actividades de extensión promover la conservación de la biodiversidad agrícola.

Palabras clave: Agrobiodiversidad, ethnicidad, uso de la suelo y cambio de uso de suelo, desarrollo, Pearl Basin Lagoon, Nicaragua

\section{Introduction}

Biodiversity in agricultural systems (agrobiodiversity) is critical to food security and ecosystem integrity (Brussaard et al. 2010, Harvey et al. 2008, Thrupp 2000). Agrobiodiversity combines the cultivation of domesticates and the conservation of wild plant species within an agroecosystem (Coomes and Ban 2004, Major et al. 2005, Perrault-Archambault and Coomes 2008). Despite its importance, agrobiodiversity has declined globally since the mid-20 ${ }^{\text {th }}$ century (Bellon 2004, Brush 2004, Jackson et al. 2007, Thrupp 2000). This decline is attributed to the spread of ideas, values, and technologies once associated with the Green Revolution, including rural development policies that encouraged adaptation of 'modern' agricultural techniques and market-oriented planting strategies (Nazarea 2005, Thrupp 2000, Zimmerer 2010).

Concerned with promoting agrobiodiversity, researchers have identified various factors that correlate with farmers' maintenance of agrobiodiversity. Strong relationships have been identified in certain regions between a farmer's ethnicity and the types and degrees of agrobiodiversity they maintain within their farming systems (Baco et al. 2007, Brush and Perales 2007, Coomes and Ban 2004, Coomes and Burt 1997, Kirby 2011, Perrault-Archambault and Coomes 2008, Perreault 2005, Trinh et al. 2003). Intriguingly, research suggests that members of indigenous or ethnic minority communities are more likely than their nonindigenous neighbors to maintain high levels of agrobiodiversity (Brush and Perales 2007, PerraultArchambault and Coomes 2008, Perreault 2005), echoing a general pattern in land use research in which 'indigenous peoples' are recognized as the global stewards of (agro)biodiversity (Ellen et al. 2000, Garí 1999, Godoy et al. 2005, Nazarea 2006, Orlove and Brush 1996, Zimmerer 2015).

Yet, the processes shaping these relationships between ethnicity and agrobiodiversity remain unclear (Veteto and Skarbø 2009). I argue that this knowledge gap reflects the challenges in accounting for the 
complexities of land use decision-making and ethnicity. Researchers have identified correlations between farm-, farmer-, and household-level characteristics and a farmer's maintenance of agrobiodiversity, but they have failed to recognize how these myriad factors may be shaped by or related to larger sociopolitical processes. The focus on ethnicity highlights this oversimplification. Ethnicities are sociocultural categories that may relate to, for example, the shared histories of group members (Barth 1969). Yet, ethnic identities, or individuals' affiliation with ethnic categories, can be influenced by sociopolitical context (Escobar 2008, Hale 2006, Wimmer 2013). Thus, to understand the relationship between ethnicity and agrobiodiversity, researchers must consider the ways in which historical and contemporary processes operating at various political scales work to influence a farmer's land use decisions in addition to how these processes may shape their ethnic identities.

In light of these considerations, I employed a political ecology framework integrating agroecological, demographic, and qualitative data collected in Caribbean Nicaragua's Pearl Lagoon Basin to determine how ethnicity influences, and how ethnic identity is influenced by, a farmer's maintenance of agrobiodiversity. This framework accounts for the variety of socio-cultural, political-economic, and agroecological factors and processes that influence land use decisions, as well as the interactions and relationships between these phenomena. In particular, this approach enables me to distinguish the ways in which specific local and extralocal political economic processes simultaneously shape the ethnic identities of and land use by Basin farmers. As such, this integrative research approach enhances the ability of a political ecological perspective to illustrate the role of complex, multi-level sociopolitical processes in shaping this dynamic socio-ecological system (Paulson and Gezon 2005).

To characterize the relationships between ethnicity and agrobiodiversity, I first determined if there are measurable differences in the levels of agrobiodiversity maintained by farmers in the Pearl Lagoon Basin that correspond with farmers' identification with the Basin's four main ethnic categories. I hypothesized that farmers who self-identify with the area's indigenous and afro-descendant groups (Miskito, Garifuna, and Creole) have more agrobiodiverse farming systems (measured in terms of species richness and the Shannon Diversity Index) than farmers who identify with the mestizo majority.

I then assessed a suite of variables previously identified to potentially influence small-scale farmers' agrobiodiversity maintenance. I expected the major factors influencing agrobiodiversity maintenance to be:

1) agricultural knowledge

2) participation in agricultural development projects, and

3) involvement with local communal land tenure systems.

I hypothesized that these key factors also relate to farmers' ethnic identities, specifically that farmers who identify with the region's historical indigenous and afro-descendant communities - the primary targets of regional agricultural extension programs-will share system of agroecological knowledge that supports agrobiodiversity maintenance. In contrast to broader patterns regarding ethnicity and agrobiodiversity, I also hypothesized that because of community land use norms, mestizo households that reside in predominantly Miskito, Creole, or Garífuna communities have more agrobiodiverse farming systems than mestizos living in more remote parts of the Basin.

\section{Background: conceptualizing ethnicity}

Ethnicities are sociopolitical groups whose members are believed to share characteristics, which might include language, heritage, homeland, religion, or value system (Barth 1969, Eriksen 2002, Wimmer 2013). Despite relative consensus on this basic definition, opinions have long diverged on how to approach ethnicity as an object of study. 'Primordialist' theories suggest these shared characteristics are tied to the common history of ethnic group members (Geertz 1973). Yet, ethnic identities, or affiliations with ethnic categories, often are fluid and context dependent (Jamieson 2003, Vincent 1974). Therefore, ethnicity can be measured as a demographic characteristic representative of traits believed to be common among its group members, or 
it can be recognized as a suite of categories of identification that are activated by an individual within particular contexts (Wimmer 2013).

Both of these seemingly contradictory conceptualizations of ethnicity are crucial for understanding the relationship between a farmers' ethnicities and their maintenance of agrobiodiversity. On one hand, ethnic categories can correspond with a mutual history (real or imagined) of a population, which may reflect the shared ethnobotanical and agroecological knowledge, livelihood strategies, and perceptions of their relationship with their natural environment that groups often develop over time in a common socio-ecological milieu (Atran 1993, Brush 2004, Michaud and Forsyth 2011, Nietschmann 1973). Simultaneously, while ethnic categories in themselves may be relatively stable constructs, individuals actively or passively affiliate with these sociopolitical categories, particularly because of the political implications of ethnicity (Escobar 2008, Gould 1998, Hale 2006, Postero 2006, Saldivar 2011, Speed 2007). This ethnic plasticity and the sociopolitical context that shape these processes are key to understanding the dynamics of ethnic identity. Further, employing a political ecology framework that disentangles this context enables me to more robustly trace how these ethnic dynamics relate to land use decision-making.

\section{The study area: the Pearl Lagoon Basin}

Situated within the Meso-American Biological Corridor ${ }^{2}$, the Caribbean Coast of Nicaragua is an important site of ethnic diversity within the country, and in Central America more widely (Jamieson 1999). This sociocultural diversity is rooted in the Coast's unique regional history. As a buccaneer outpost and then through a colonial relationship with the British (rather than the Spanish), the Caribbean (or Miskito) Coast was home to indigenous populations and marooned slaves throughout the post-Contact period (c. 1620). When formally annexed by Nicaragua in $1894^{3}$, the British required special protections for the Coast's indigenous and afro-descendants populations (Pineda 2006). Following decades of relative autonomy, the threat of further incorporation into the Nicaraguan nation provoked a US-backed counter-insurgency (or Contra War) against the Sandinista government (1979-1987) (Hale 1994). Formal autonomy was negotiated in a ceasefire agreement, granting cultural, political, and material rights (i.e. natural resources) to the indigenous and afro-descendant communities ${ }^{4}$ of Nicaragua's Caribbean Coast (Goett 2006).

In addition to indigenous and afro-descendant populations, the North and South Caribbean Coast Autonomous Regions (RACCN and RACCS respectively) also include Mestizo ${ }^{5}$ residents from Nicaragua's Pacific and Highland regions that been migrating to the Coast since annexation. A small population until the end of the Contra War, mestizos are now a strong majority in the Caribbean Regions (63-73\% of the population) (Brunnegger 2007, Jamieson 1999). Notably, many mestizo are rural migrants 'squatting' on land granted through the Autonomy Statute to indigenous and afro-descendant communities and are not all accounted for in the formal census (Jamieson 1999). The history of intermarriage between the region's various ethnic groups and the politicization of ethnic identity further complicates quantifying local ethnic populations. Many individuals living on the Coast claim affiliation with a multiple ethnic categoriesincluding mestizo (Jamieson 1999, Pineda 2006). However, exercising an affiliation with one (or more) of the indigenous or afro-descendant groups is requisite to benefit from rights (such as the right to land) afforded by the Autonomy Statute and subsequent legal rulings (Autonomy Statute for the Regions of the Atlantic Coast

\footnotetext{
${ }^{2}$ The Meso-American Biological Corridor holds 7\% of the world's biodiversity, and the conservation of an intact and healthy ecosystem in this region is critical for maintaining a connection for the flora and fauna of North and South America (Conservation International 2014).

${ }^{3}$ This incorporated region was known as the Department of Zelaya.

${ }^{4}$ Afro-descendant communities are technically referred to as comunidades étnicas, or ethnic communities, in Law 445 , or the Demarcation Law. This law, passed in 2002, established a communal land titling program throughout the Caribbean Regions, which was believed to better enable the Region's pueblos indígenas and comunidades étnicas to manage and protect their land and resource rights (Law 445: Law of the Community Property Regime of the Indigenous Peoples and Ethnic Communities of the Autonomous Regions of the Atlantic Coast of Nicaragua and the Rivers of Bocay, Coco, Indio, and Maiz 2002).

${ }^{5}$ Spanish-speakers of mixed European and Amerindian descent.
} 
of Nicaragua, Law no. 28, Art. 9 [1987]). Therefore, the number of individuals who identify (at least in part) as mestizo are likely much higher than estimated (Jamieson 1999).

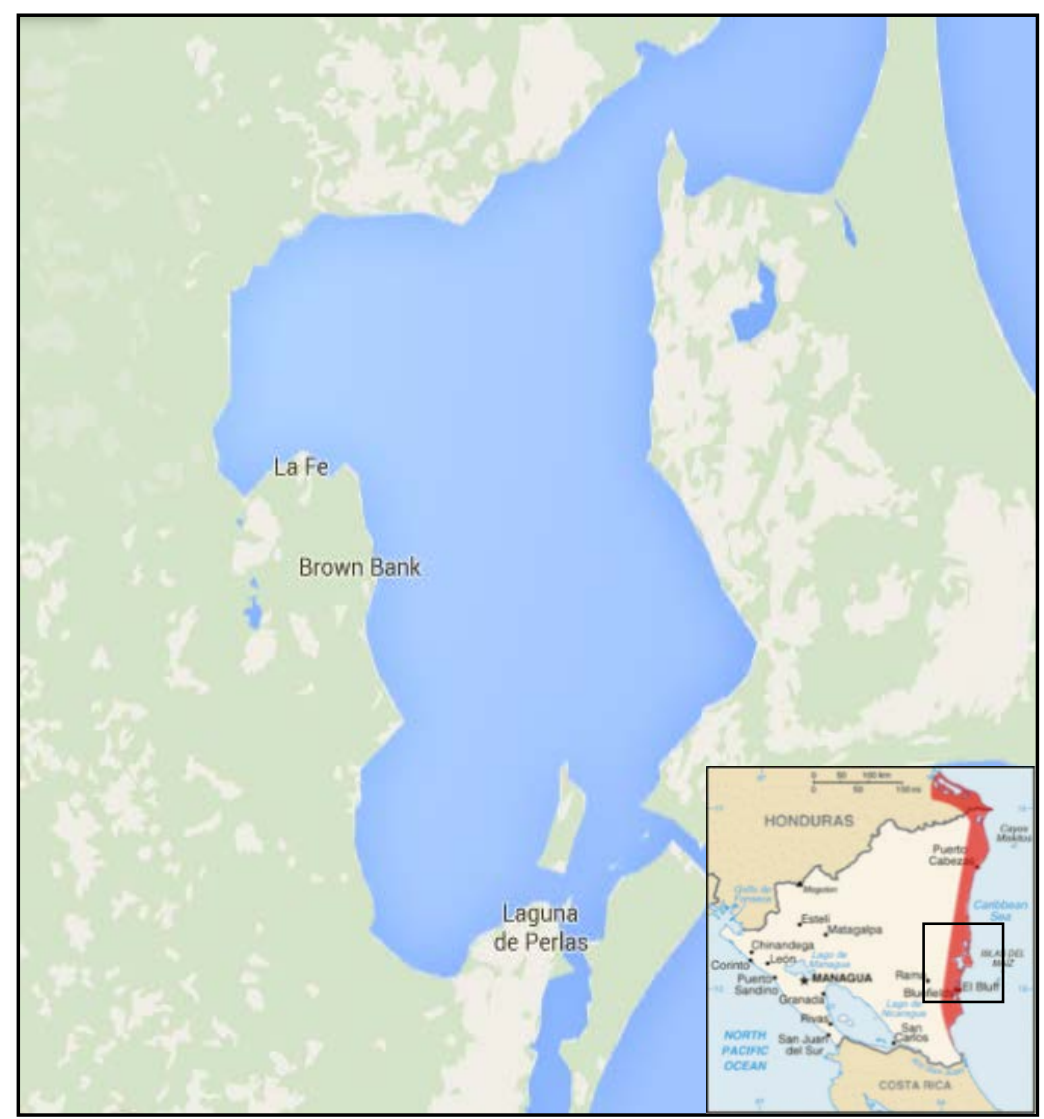

Figure 1: A map of Nicaragua's Pearl Lagoon Basin. Sources: Google Maps and Wiki Commons 2015.

Located in the RACCS, the Pearl Lagoon Basin (Figure 1) was selected as the focal site for this research because of its pronounced ethnic diversity, which includes indigenous, afro-descendant, and mestizo populations who historically maintained ethnically-distinct land use patterns (Helms 1971, Jamieson 1999, Nietschmann 1973). The farming practices of the Basin's indigenous and afro-descendant Miskito, Garífuna, and Creole populations have been characterized as biologically-diverse swidden agroforestry systems that include cassava, plantain, coconut, beans, various fruit trees, wild herbs, and a variety of other domesticated and wild species (Coe and Anderson 1996, 1997). In contrast, recently migrated mestizo populations tend to focus on cattle ranching (Jamieson 1999).

While the people of the Coast have been integrated into global political economic systems throughout the post-Contact period (c. 1620) (Helms 1969, 1971, Nietschmann 1973), the Pearl Lagoon Basin is currently experiencing an era of increased connectedness following the development of the region's first 'highway' $^{6}$ and the possible construction of a trans-isthmus shipping canal (Anderson 2015). These

\footnotetext{
${ }^{6}$ This $80 \mathrm{~km}$ unpaved dirt road was completed in 2007 and connects Pearl Lagoon, the largest community in the Pearl Lagoon Basin, to the national paved highway system in the town of Rama. While, according to local informants, this road was a point of discussion for decades, it was completed under the direction of the Instituto de Desarrollo Rural (IDR) with financial help from the Japanese government (Martínez et al. 2007). Importantly, this project was not undertaken
} 
development activities have profound impacts upon regional ecological and social systems (Stevens et al. 2014). Additionally, a number of governmental and non-governmental agricultural development programs are currently operating in the Basin, which may influence local and regional agrobiodiversity.

These agriculturally-focused organizations include:

1) NicaCaribe, a federal program that distributes already common crops to local farmers in an effort to promote food security throughout the Caribbean Region (Mi Familia 2015)

2) the Nicaraguan Institute of Agricultural Technology (INTA), a federal agricultural extension program focusing on animal husbandry (INTA 2015)

3) the Black Farmers Cooperative, a government-backed—but locally managed—cooperative working to encourage coconuts cultivation around the Pearl Lagoon for export

4) Bluefields Indian and Caribbean University, a regional university experimenting with supplying market-oriented crops to select farmers (BICU 2015), and

5) the Foundation for the Autonomy and Development of the Atlantic Coast of Nicaragua (FADCANIC), an internationally-funded regional non-governmental organization (NGO) that operates an nursery and agro-forestry training center in the Pearl Lagoon Basin and has introduced novel plant species to the Basin's farmers (FADCANIC 2014).

In light of the factors associated with this period of increased connectedness, the Pearl Lagoon Basin served as an ideal focal region for understanding the processes and issues shaping how a farmer's ethnicity relates to their agrobiodiversity maintenance in the face of rapid change.

\section{Methods}

A suite of qualitative, demographic, and agroecological data was used to explore the factors regulating farmer agrobiodiversity maintenance in the Pearl Lagoon Basin, Nicaragua (Table 1). From 2009 - 2014, quantitative and qualitative data that previous research shows to correlate with a farmer agrobiodiversity maintenance were collected through: 1) surveys conducted with 163 farmers throughout the Pearl Lagoon Basin and 2) geo-referenced household survey data collected by a collaborating research team based at Michigan State University (MSU) ${ }^{7}$ (Table 1). Additionally, ethnographic data was collected in 2013-2014 through participant observation and key informant interviews $(\mathrm{N}=30)$.

Based on a household census developed by MSU, their team surveyed a random sample of households from around the Pearl Lagoon Basin in 2009, 2010, 2012, and 2014. My investigation used a stratified subsample of 163 of the 445 households in the MSU study that identified themselves as participating in farming. With the help of two local field assistants, I administered agrobiodiversity surveys in the wet (or main agricultural) season (August-December 2013) with each of these farmers, who reside in 8 residential communities (Table 2), to gather information about the factors identified in previous literature as important to the maintenance of agrobiodiversity, but absent from MSU's surveys. ${ }^{8}$ These factors include the farmer's age, the number of years s/he has engaged in agriculture, and the potentially multiple ethnicities with which the farmer self-identifies. Farm size and age were also recorded. Plant surveys were conducted with each farmer to develop complementary agrobiodiversity metrics, specifically species richness and the Shannon Diversity Index.

until after the establishment of an African Palm oil plantation in Kukra Hill, a community 17 km inland from Pearl Lagoon, and was chiefly intended to help foreign investors expand the agro-industrial African Palm operation (IFC 2010). A dirt spur connects Pearl Lagoon to the Kukra Hill-Rama road.

7 This project was funded by a National Science Foundation (NSF) Dynamics of Coupled and Natural and Human Systems grant, \#0815966.

${ }^{8}$ The location of farmers' households, the size of their villages, household wealth indices, and household livelihood activity information was provided by MSU. 


\begin{tabular}{|c|c|}
\hline Factor & Source \\
\hline \multicolumn{2}{|l|}{ Farm Factors } \\
\hline Age of farm & (Aguilar-Støen et al. 2008, Coomes and Ban 2004) \\
\hline Size of farm & (Coomes and Burt 1997, Perrault-Archambault and Coomes 2008) \\
\hline Homegarden (presence/absence) & (Coomes and Ban 2004) \\
\hline Pasture (presence/absence) & (Zimmerer 2004) \\
\hline Distance from household to farm & (Wezel and Ohl 2005) \\
\hline \multicolumn{2}{|l|}{ Farmer Factors } \\
\hline Farmer age & (Armah et al. 2013, Perrault-Archambault and Coomes 2008) \\
\hline Years of farming experience & (Armah et al. 2013) \\
\hline Gender & (Perrault-Archambault and Coomes 2008) \\
\hline Ethnicity & $\begin{array}{l}\text { (Baco et al. 2007, Brush and Perales 2007, Coomes and Ban 2004, } \\
\text { Coomes and Burt 1997, Kirby 2011, Perrault-Archambault and Coomes } \\
\text { 2008, Perreault 2005, Trinh et al. 2003) }\end{array}$ \\
\hline \multicolumn{2}{|l|}{ Household Factors } \\
\hline 'Remoteness' & (Major et al. 2005, Nazarea 2005, Wezel and Ohl 2005) \\
\hline Household livelihood diversity & (Aguilar-Støen et al. 2008, Lamont et al. 1999, Perreault 2005) \\
\hline Household wealth & (Coomes and Ban 2004) \\
\hline \multicolumn{2}{|l|}{ Political Factors } \\
\hline Size of community of residence & (Perrault-Archambault and Coomes 2008) \\
\hline Access to credit & (Abbott 2005, Armah et al. 2013) \\
\hline $\begin{array}{l}\text { Affiliation with agricultural } \\
\text { development organizations }\end{array}$ & (Abbott 2005) \\
\hline
\end{tabular}

Table 1: Factors identified by previous research to influence agrobiodiversity.

\begin{tabular}{|l|l|l|l|}
\hline Community & $\begin{array}{l}\text { Population } \\
\text { in 2006 }\end{array}$ & Dominant ethnic make-up & $\begin{array}{l}\text { Chief economic sectors (of equal } \\
\text { importance) }\end{array}$ \\
\hline Pearl Lagoon & 2,540 & $\begin{array}{l}\text { Creole, Miskito, Garífuna, } \\
\text { mestizo }\end{array}$ & Fisheries, Agriculture, Tourism \\
\hline Raitipura & 250 & Miskito & Fisheries, Agriculture \\
\hline Awas & 93 & Miskito & Fisheries, Agriculture \\
\hline Kakabila & 497 & Miskito & Fisheries, Agriculture \\
\hline Brown Bank & 202 & Garífuna, Creole & Fisheries, Agriculture \\
\hline La Fe & 110 & Garífuna, mestizo & Fisheries, Agriculture \\
\hline Orinoco & 1,010 & Garífuna, mestizo & Fisheries, Agriculture \\
\hline Pueblo Nuevo & Unknown & Mestizo & Agriculture \\
\hline
\end{tabular}

Table 2: Communities included in study. Source: Beer and Vanegas 2007.

\section{Agrobiodiversity assessment}

Species richness, the number of species present in a landscape (Gotelli and Colwell 2001), is a common method of measuring biodiversity in agricultural and other ecological systems. A farmer, however, may have (and need) only one plant of a particular species (e.g. a mango tree) or many of a given species (e.g. corn). Thus, I also calculated the Shannon Diversity Index ${ }^{9}$ for each farmer, which takes into account species richness and evenness (relative abundance of species) within an ecological community (Beals et al. 2000). For example, a Shannon Index distinguishes between an agroecosystem comprised of one mango tree

\footnotetext{
${ }^{9}$ Because abundance estimates of grasses are difficult, these plants are excluded when calculating Shannon Indices.
} 
and 10 corn stalks as compared to a farm with 10 of each species. While equal in richness, diversity in the second theoretical farm is more evenly distributed. Together these metrics provide an assessment of a farmer's crop (and non-crop) diversity - which is important for food security (Jackson et al. 2007, Thrupp 2000) — and also habitat potential, a noted benefit of high agrobiodiversity (Brussaard et al. 2010, Harvey et al. 2008, McNeely and Scherr 2003).

Plant surveys were conducted using the primary language of the farmers: Creole, Spanish, and Miskito. Plant names were verified with community leaders in each language. Farmers were presented with a list of all plant species previously identified to be part of local ethnobotanical portfolio (Coe 2008, Coe and Anderson 1996, Coe and Anderson 1997), as well as recently introduced plants identified in pilot surveys. Farmers were asked to state whether a species was present within their farming area and to estimate the abundance of each species present. When possible, surveys were administered with the primary farmer (selfidentified during initial household visits) on their farm and involved a tour. If their schedule did not permit an on-farm interview - many farmers do not visit their (arduously distant) farms daily—surveys took place in the farmers' communities. Surveys lasted ca. 1-2 hours, reflecting variable time spent walking farms.

While these estimations do not accurately account for all of the species present within a farm, this method gauges the planned diversity. Most farms in the Basin are complex agro-forestry systems, which often include a plethora of wild plant species. Some of these species, however, are considered to be 'bush' (or wild) species that a farmer may believe has no use value. Therefore, recalls and estimations relayed a farmer's agroecological knowledge and provided agrobiodiversity information reflecting the farmer's direct agricultural decisions.

Qualitative information was collected through participant observation conducted while assisting with farm labor and during agricultural extension workshops and interviews with farmers, community leaders, regional agricultural development specialists, and academics knowledgeable about the local socio-ecological system. This information and survey data was used to identify 24 key informants (selected to represent each community/ethnic group) whose farms were revisited and who were interviewed during the dry season (January-May 2014). These interviews focused on topics including agricultural knowledge, intra-household decision-making, historical and current cultivation practices, household livelihood strategies, involvement with agricultural development organizations, and the dynamics of ethnic identification. Additionally, two officials from each of the three major agricultural development organizations $(\mathrm{N}=6)$ were interviewed to gather detailed accounts of the history of these projects, their funding sources, and their development goals.

Multiple regression analyses were used to determine the strength of the relationships between farmers' agrobiodiversity metrics and various household and farm(er) factors (Carr 2008) on groups of related factors to identify significant predictor variables of species richness and the Shannon Index. These four categories include:

1) farm factors (farm age, size, distance from household, and presence or absence of homegarden or pasture)

2) farmer factors (age, gender, years farming, and ethnicity)

3) household factors (distance from road, livelihood diversity, and wealth), and

4) political-economic factors (community of residence ${ }^{10}$, access to credit, and affiliation with agricultural development agencies).

Analyses were performed 'step-wise', carrying statistically significant factors $(\alpha \leq 0.05)$ from the first analyses into the second and the statistically significant variables from the second group of equations to the third, etcetera. The end results were considered to be best-fit models that identify the most significant factors

\footnotetext{
${ }^{10}$ Because community is a categorical variable with 7 levels (the neighboring-and historically linked-Miskito communities of Raitipura and Awas are treated as a single community), the overall effect of community on the agrobiodiversity metrics was determined by an analysis of deviance.
} 
predicting each agrobiodiversity metric. ${ }^{11}$ By exploring groups of variables in stages, step-wise regressions identify secondary factors that may also be relevant to land use decision-making, which can further explored through qualitative data analyses.

Qualitative data was analyzed using RQDA (Huang 2014). Statistically significant relationships identified and common themes derived inductively from fieldnotes (Bernard 2006) were used as a guide for coding the qualitative data collected over the course of fieldwork. Qualitative analyses elucidated the sociocultural, political, and economic factors that encourage or hinder the maintenance of agrobiodiversity by some farmers in the Basin more than others, with a focus on explaining the processes that influence the significant correlations that were identified through regression analyses. Further, qualitative data was vital for understanding the dynamics of ethnic identification and its relationship to land use strategies. Interviews with agricultural development practitioners explored the history of these projects and their goals. All analyses were conducted in R (R Core Team 2013)

\section{Results of quantitative data analyses}

Demographic statistics in the sample population are summarized in Table 3 (163 farmers in 8 communities). Data is reported as the mean \pm standard error, and communities are listed in order of their distance from the regional road, with the Basin's largest community (Pearl Lagoon) positioned at the road's terminus. Because of the informal (and illicit) settlement patterns of Pueblo Nuevo, its official population is not known. However, experience in the community leads me to believe that it is among the Basin's largest. While the average age of a primary farmer is 46.2 years ( \pm 1.0 ), Pearl Lagoon farmers are significantly older on average than farmers in the Basin's other communities (57.8 years \pm 1.9 ). Additionally, each community contains survey participants who include only that population's dominant ethnicity within their identity portfolio, as well as others who include multiple ethnicities.

\section{Multivariate analyses}

The first set of regression models (Step 1) describe the potential relationships between farm-level factors and the agrobiodiversity metrics (Table 4). In models predicting species richness and the Shannon Index, the age of the farm is a significant predictor of agrobiodiversity. Additionally, farmers with homegardens were identified as maintaining greater species richness than do farmers without gardens. This is consistent with previous research indicating that homegardens play a prominent role in species and variety conservation among small-scale farmers (Coomes and Ban 2004).

The second set of models include significant farm-level factors (from Step 1) and farmer-level factors. Farmers' ethnic identity is the only farmer-level variables identified as a significant predictor of agrobiodiversity (Table 5). While preliminary analyses revealed that Creole, Garifuna, and Miskito identities are all correlated with high levels of agrobiodiversity, multiple regression analysis identified the aggregate category, 'Indigenous and/or Afro-descendant', as the most significant predictor. Because of the similar land use practices and overlapping histories of these populations, this broader category is used in subsequent analyses. Notably, farmers that identify with Garifuna (average species richness $=36 \pm 1.9$ ) and Creole (richness $=35 \pm 1.9$ ) have higher average levels of agrobiodiversity than do farmers who include Miskito in their identity portfolios (richness $=30 \pm 1.8$ ). For mestizo farmers, species richness was the lowest $(25 \pm 1.8$ ), although significantly higher (33 \pm 1.6 ) for farmers who include mestizo in their identity but reside in indigenous and afro-descendant communities.

\footnotetext{
${ }^{11}$ The order in which groups of factors are included in regression analyses developed 'step-wise' can impact model outcomes. Therefore, alternative analyses were explored, incorporating the groups of factors (i.e. farm, farmer, household, and political economic) in different orders. Ultimately, while significant factors slightly vary in intermediate steps of these alternative analyses, the most predictive models remain the same.
} 


\begin{tabular}{llllll}
\hline Community & $\begin{array}{l}\text { Distance to } \\
\text { road } \\
\text { terminus }\end{array}$ & Population & Sample \# & Ethnic make-up of sample & $\begin{array}{c}\text { Mean } \\
\text { farmer }( \pm \text { standard } \\
\text { error) }\end{array}$ \\
\hline Pearl Lagoon & $\sim 0 \mathrm{~km}$ & 2,540 & 17 & $\begin{array}{l}\mathrm{C}=7, \mathrm{G}=1, \mathrm{M}=1, \\
\mathrm{Mz}=1, \mathrm{ME}=7\end{array}$ & $57.8( \pm 1.9)$ \\
Raitipura/Awas & $\sim 1.6 \mathrm{~km}$ & 343 & 12 & $\mathrm{C}=1, \mathrm{M}=6, \mathrm{ME}=5$ & $48( \pm 4.1)$ \\
Kakabila & $\sim 8.8 \mathrm{~km}$ & 497 & 38 & $\mathrm{M}=19, \mathrm{ME}=19$ & $43.9( \pm 2.1)$ \\
Brown Bank & $\sim 13.3 \mathrm{~km}$ & 202 & 14 & $\mathrm{C}=5, \mathrm{ME}=9$ & $48.2( \pm 3.6)$ \\
La Fe & $\sim 19.6 \mathrm{~km}$ & 110 & 14 & $\mathrm{G}=5, \mathrm{ME}=9$ & $42.4( \pm 3.8)$ \\
Orinoco & $\sim 25 \mathrm{~km}$ & 1,010 & 32 & $\mathrm{G}=24, \mathrm{Mz}=1, \mathrm{ME}=7$ & $47.7( \pm 2.4)$ \\
Pueblo Nuevo & $\sim 40.7 \mathrm{~km}$ & unknown & 36 & $\mathrm{G}=2, \mathrm{Mz}=30, \mathrm{ME}=4$ & $43.6( \pm 1.9)$ \\
Total & & $>4,702$ & 163 & $\mathrm{C}=13, \mathrm{G}=32, \mathrm{M}=26,46.2( \pm 1.0)$ \\
\end{tabular}

Table 3: Demographic and geographic characteristics of the sample population to which agrobiodiversity surveys were administered. For ethnicity, $\mathrm{C}=$ Creole, $\mathrm{G}=$ Garifuna, $\mathrm{M}=$ Miskito, Mz = Mestizo , ME = Multiple Ethnicities. Sources: Beer and Vanegas 2007 and this study.

Step 3 incorporates household-level factors in addition to the significant farm- and farmer-level factors identified in Step 2. In contrast to previous research that identified positive correlations between household wealth (Coomes and Ban 2004) or 'remoteness' (Major et al. 2005, Nazarea 2005) and a farmer's maintenance of agrobiodiversity, these factors are not significant predictors of agrobiodiversity maintenance in these models (Table 6). The addition of these variables does not alter the outcomes of the farm factor + farmer factor model predicting the Shannon Index, but nullifies the effect of mestizo identity upon species richness. Therefore, while mestizo identity is a predictor of the species richness, variation in species richness is better explained by factors such as a farmer's age, the age of their farm, whether they maintain a homegarden, and if they include an indigenous or afro-descendant ethnicity within their identity portfolio.

\begin{tabular}{lllll}
\hline $\begin{array}{l}\text { Factor } \\
\text { Category }\end{array}$ & Factor & Data Description & $\begin{array}{l}\text { Species } \\
\text { Richness }\end{array}$ & $\begin{array}{l}\text { Shannon } \\
\text { Index }\end{array}$ \\
\hline Farm & Farm Age & $\overline{\mathrm{x}}=40.4( \pm 36.6)$ years & $* * *$ & $* * *$ \\
& Farm Size & $\overline{\mathrm{x}}=19.7( \pm 27.2)$ ha & NS & NS \\
& Distance from Household & $\overline{\mathrm{x}}=63.3( \pm 11.6)$ minutes & NS & NS \\
& Homegarden & Presence $=98$ & $* * *$ & NS \\
& Pasture & Presence $=66$ & NS & NS \\
\hline
\end{tabular}

Table 4: Multiple regressions of farm-level factors. 163 farms were included in the analyses. Standard deviation is reported for all means. Asterisks represent level of statistical significance, where $* * *=\mathrm{p}<0.001$. Non-significant effects are indicated by NS. Positive and negative directionality of significant regressions are indicated by $(+)$ and $(-)$, respectively.

Step 2 revealed that a farmer's inclusion of an indigenous or afro-descendant ethnicity in their identity portfolio is a significant predictor of the species richness they maintain, while inclusion of mestizo is negatively correlated with species richness and the Shannon Index (Figure 2). The age of the farm remains significant in species richness and Shannon Index models. The maintenance of a homegarden also remains a significant predictor of a species richness. 


\begin{tabular}{|c|c|c|c|c|}
\hline $\begin{array}{l}\text { Factor } \\
\text { Category }\end{array}$ & Factor & Data description & Species richness & $\begin{array}{l}\text { Shannon } \\
\text { Index }\end{array}$ \\
\hline \multirow[t]{5}{*}{ Farmer } & Farmer Age & $\overline{\mathrm{x}}=46.2( \pm 13.1)$ years & $*(+)$ & $*(+)$ \\
\hline & Years Farming & $\overline{\mathrm{x}}=25.4( \pm 14.9)$ years & NS & NS \\
\hline & Gender(s) & $\begin{array}{l}95 \text { Men, } 39 \text { Women, } \\
27 \text { Couples }\end{array}$ & NS & NS \\
\hline & $\begin{array}{l}\text { Indigenous or Afro- } \\
\text { descendant Identity }\end{array}$ & $\mathrm{N}=131$ & $*(+)$ & NS \\
\hline & Mestizo Identity & $\mathrm{N}=60$ & $* *(-)$ & $* *(-)$ \\
\hline \multirow[t]{3}{*}{ Farm } & Farm age & & $* *(+)$ & $* * *(+)$ \\
\hline & Homegarden & & $* *(+)$ & \\
\hline & Pasture & & & \\
\hline
\end{tabular}

Table 5: Multiple regressions of farmer factors. 163 farms were included in the analyses. Standard deviation is reported for all means. Asterisks represent level of statistical significance, where $*=\mathrm{p}<0.05, * *=\mathrm{p}<0.01, * * *=\mathrm{p}<0.001$. Non-significant effects are indicated by NS. Positive and negative directionality of significant regressions are indicated by $(+)$ and $(-)$, respectively.

\begin{tabular}{|c|c|c|c|c|}
\hline $\begin{array}{l}\text { Factor } \\
\text { Category }\end{array}$ & Factor & Data Description & $\begin{array}{l}\text { Species } \\
\text { Richness }\end{array}$ & $\begin{array}{l}\text { Shannon } \\
\text { Index }\end{array}$ \\
\hline \multirow[t]{3}{*}{ Household } & Distance from Road & Based on residential community & NS & NS \\
\hline & $\begin{array}{l}\text { Household Livelihood } \\
\text { Diversity }\end{array}$ & $\overline{\mathrm{x}}=1.7( \pm 1.2)$ activities & NS & NS \\
\hline & Household Wealth Index & Asset-based & NS & NS \\
\hline \multirow[t]{2}{*}{ Farm } & Farm Age & & $*(+)$ & $* *(+)$ \\
\hline & Homegarden & & $* *(+)$ & \\
\hline \multirow[t]{3}{*}{ Farmer } & Farmer Age & & $* *(+)$ & $*(+)$ \\
\hline & $\begin{array}{l}\text { Indigenous or Afro- } \\
\text { descendant Identity }\end{array}$ & & $* *(+)$ & \\
\hline & Mestizo Identity & & NS & $*(-)$ \\
\hline
\end{tabular}

Table 6: Multiple regression of household factors. 163 farms were include in the analyses. Standard deviation is reported for all means. Non-significant effects are indicated by NS. Asterisks represent level of statistical significance, where $*=\mathrm{p}<0.05, * *=\mathrm{p}<0.01, * * *=\mathrm{p}$ $<0.001$. Positive and negative directionality of significant regressions are indicated by $(+)$ and $(-)$, respectively.

Step 4 of regression analyses includes political-economic factors in addition to the significant predictor variables identified in Step 3 (Table 7). Intriguingly, each of these political economic factors has a significant relationship with species richness and the Shannon Index, with farmers residing in communities closer to the regional road tending to have higher median species richness (and Shannon Index) than farmers further from the road (Figure 3). Further, the inclusion of the political economic factors nullifies the effect of ethnicity in the species richness and Shannon Index models. The only remaining significant predictors from the previous regression models are: 1) age of a farmer and species richness and 2) presence of a homegarden 
and species richness. In addition to these relationships, political economic variables-which include community of residence, access to credit, and working with an agricultural development project-best explain the quantitatively measured differences in agrobiodiversity among farmers in the Pearl Lagoon Basin (Table 7). The variables in the final regression models explain $37 \%$ of the variation in species richness among farmers $\left(R^{2}=0.37\right)$ and $34 \%$ of the variation for Shannon Indices $\left(R^{2}=0.34\right)$. Re-running a final regression without including the non-significant factors did not improve the model fit.
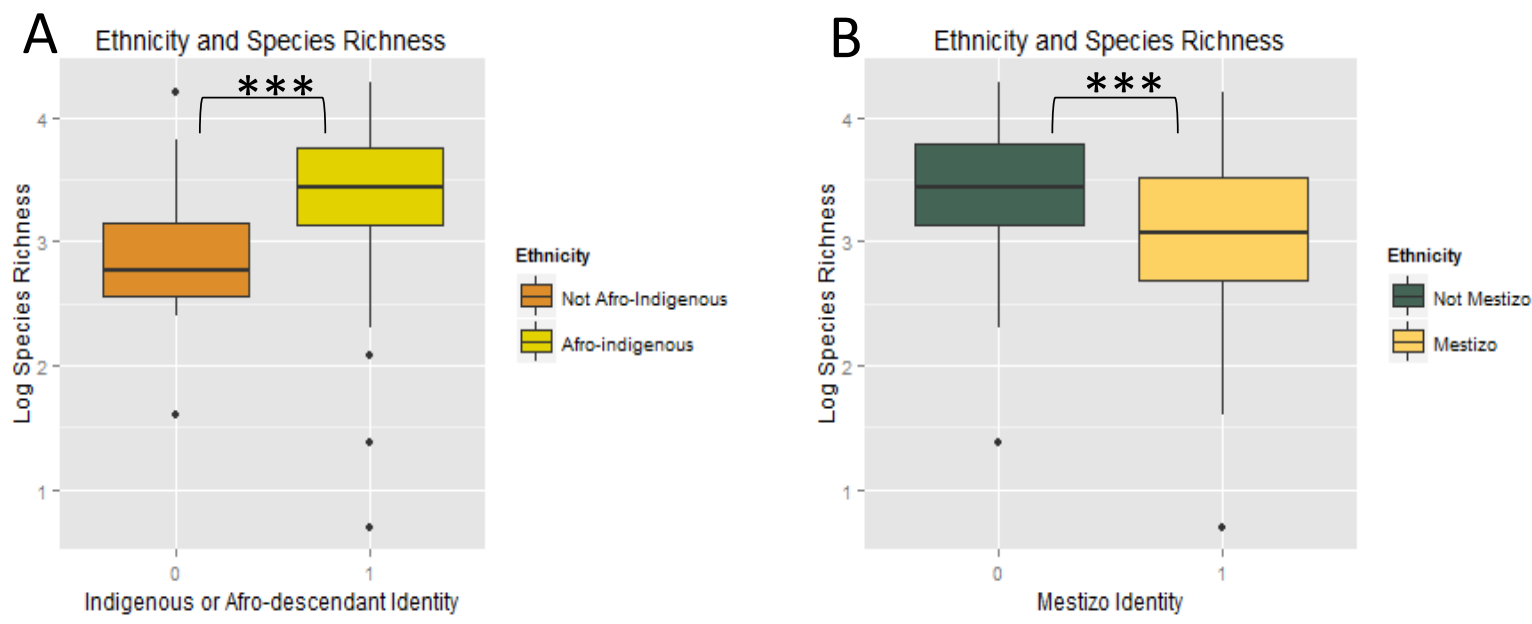

Figure 2: The relationship between ethnicity and agrobiodiversity in the Pearl Lagoon Basin, NI. Box and whisker plots of the relationship between ethnic identity and agrobiodiversity maintenance, as assessed by species richness. Ethnic identity is binned in two ways: individuals who include indigenous or afro-descendant identities (including Miskito, Creole, or Garifuna) within their identity portfolios (A) and individuals who include mestizo (B). Center lines represent the median log-transformed species richness for a given ethnic binning, the top and bottom of each box represents the upper and lower quartiles (respectively) and dots represent outliers 1.5 times greater than or less than the upper and lower quartiles, respectively. Asterisks represent level of statistical significance, where $* * *=p<0.001$.

\begin{tabular}{|c|c|c|c|c|}
\hline Factor category & Factor & Data description & Species richness & $\begin{array}{l}\text { Shannon } \\
\text { Index }\end{array}$ \\
\hline \multirow{3}{*}{$\begin{array}{l}\text { Political } \\
\text { Economic }\end{array}$} & Community & $\mathrm{N}=7$ & * & $* *$ \\
\hline & Access to credit & Yes $=27$ & $*(+)$ & $*(+)$ \\
\hline & Ag. dev. affiliation & $\mathrm{N}=102$ & $* * *(+)$ & $*(+)$ \\
\hline \multirow[t]{2}{*}{ Farm } & Farm age & & NS & NS \\
\hline & Homegarden & & $* *(+)$ & \\
\hline \multirow[t]{3}{*}{ Farmer } & Farmer age & & $*(+)$ & NS \\
\hline & $\begin{array}{l}\text { Indigenous or Afro- } \\
\text { descendant identity }\end{array}$ & & NS & \\
\hline & Mestizo identity & & & NS \\
\hline
\end{tabular}

Table 7: Multiple regression of political-economic factors. 163 farms were included in the analyses. 


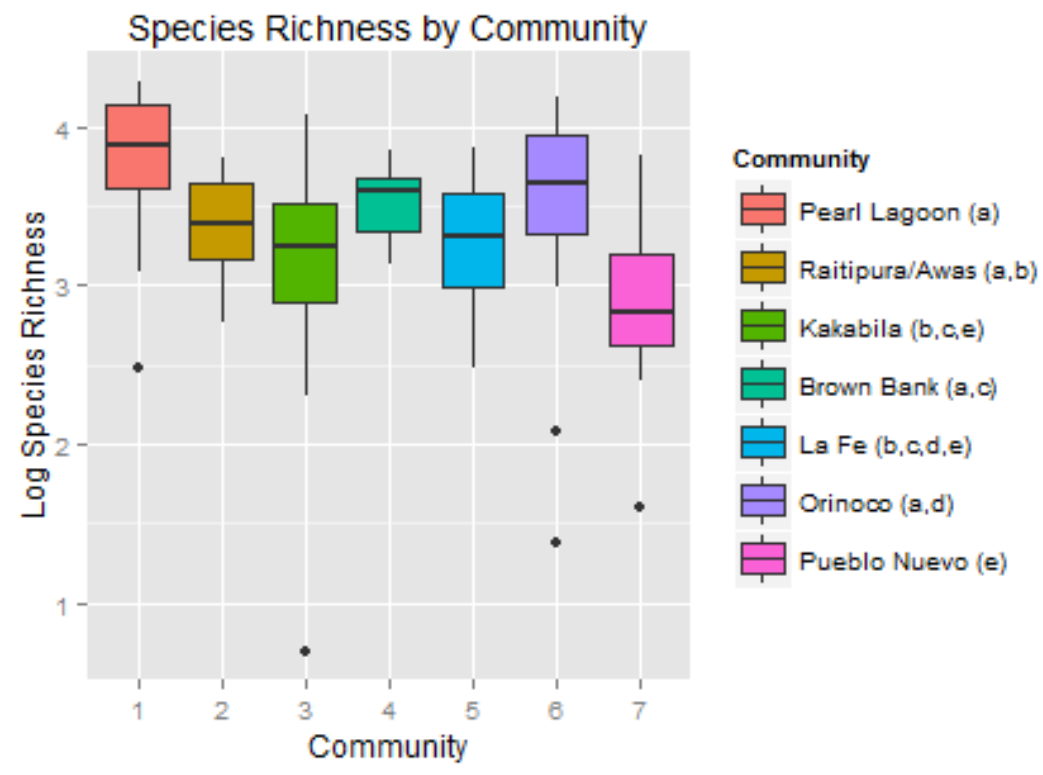

Figure 3: The relationship between community and species richness in the Pearl Lagoon Basin, NI. Asterisks represent level of statistical significance, where $*=\mathrm{p}<0.05, * *=\mathrm{p}<0.01$, *** $=\mathrm{p}<0.001$. Non-significant effects are indicated by NS. Positive and negative directionality of significant regressions are indicated by $(+)$ and (-), respectively.

\section{Results of qualitative data analyses}

While a Pearl Lagoon Basin farmer's ethnic identity strongly correlates with the species richness and Shannon index of their farm, the most robust predictors of a farmer's maintenance of agrobiodiversity were:
1) a farmer's age
2) a farmer's maintenance of a garden
3) a farmer's affiliation with an agricultural development organization
4) a farmer's access to credit, and
5) a farmer's community of residence.

Analysis of the corresponding qualitative data elucidates the relationships between these factors and provides insights into how they may shape ethnicity-agrobiodiversity relationships. In particular, qualitative data highlights the ways in which age, experience, and the position of agriculture in the life history of farmers influence their land use strategies, and in turn, the varying degrees of agrobiodiversity that they maintain in their agricultural systems. Further, this data reveals the role of ethnicity-based rights characteristic of Nicaragua's Caribbean Coast Autonomous Regions in shaping the observable relationships between ethnicity and agrobiodiversity in the Pearl Lagoon Basin. Specifically, these rights influence a farmer's access to land and their ability to benefit from agricultural development programs working in the region.

\section{Age and experience}

Residents of the Basin, particularly those in the historically afro-indigenous communities on the lagoon shores, describe a history of diversified household livelihood strategies including: fishing, various forms of local and extra-local wage labor, and agroforestry-which includes the conservation of 
ethnobotanically-important wild species and the cultivation of domesticates, such as cassava (Manihot

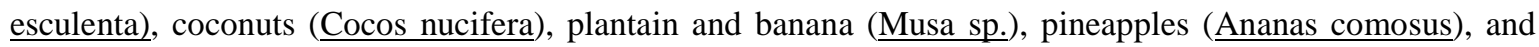
dasheen (Colocasia esculenta). Farmer interviews also revealed the ways in which livelihood activities shift over the course of an individual's life. As a farmer from Pearl Lagoon who was a dedicated fisherman for much of his life explained, "...young people are supposed to go out and fish or look for work. We older folks are the ones that take responsibility for growing food" (interview 8/6/2013).

This pattern is gendered. Throughout the Basin, more men than women take responsibility for the family farm ( $\mathrm{N}=95$ men versus $\mathrm{N}=40$ women). However, within many households $(\mathrm{N}=28)$ men and women describe sharing agricultural decision-making. No significant gender differences were found in agricultural knowledge. Both sexes grow similar plants in similar configurations, engage in farming throughout their lives, and can serve as reservoirs of local ethnobotanical knowledge. However, labor roles were gendered, with women periodically receiving assistance from younger men for physically demanding tasks-although older men similarly rely on the younger generations.

Youth tend only to engage in farming when helping older generations-an activity through which agroecological knowledge is passed down. The family farm is generally the domain of the oldest living generation. This is particularly true for farmers from the town of Pearl Lagoon, most of whom farm in Rocky Point, an area along the new road. Here, the average age of the primary farmer is 58 years old $( \pm 7.3)$. The oldest farmers still working in Rocky Point are in their late 70s. For older Basin farmers, farming can be perceived as a post-retirement occupation. As a 60 year old farmer in Orinoco stated, "You must plant a little of each thing and have things for eat... My father and grandfather stated, 'you must prepare when you're young. You can't prepare when you are old. You no want beg when you is old--you may not get"' (interview 4/10/14). Younger men and women may participate in farming, but generally focus on fishing or migrate for paid work. Older farmers focus solely on their farms and utilize agrobiodiverse planting strategies that rely heavily on perennial plants to lessen the burden of day-to-day work (Figure 4). One farmer stated that, "If you no plant, you no have... If you only plant plantain, you only have plantain... Every year you must add to [your farm], planting more and more fruit trees, make it dense" (interview 2/5/14). An elder from Pearl Lagoon pointed out, farmers like her have a lot of mixed fruit trees, so that they "have time for relax" and still meet their subsistence needs (interview 8/8/13).

Homegardens also serve as an important part of farmers' planting strategies across age, ethnicity, and communities of residence (Tables 4-7). Gardens serve as sites of subsistence resources that require relatively little effort to obtain, an observation that supports previous research (Aguilar-Støen et al. 2008, Coomes and Ban 2004, Lamont et al. 1999, Major et al. 2005, Perrault-Archambault and Coomes 2008, Trinh et al. 2003). This is particularly important for older farmers who are unable to travel regularly to their farm. A Pueblo Nuevo farmer in his mid 60s told me that he had abandoned his farm altogether, only growing foods in his half-hectare garden. As he put it, he is simply "too old to work" the farm (interview 10/23/13). Further, a La Fe farmer in his late 60s stated that his overall goal was "to relax" and that to do so, "you gotta plant in town the fruits, man. Or else you have to live on the farm, because if you ain't there, the animals will eat them all up" (interview 10/10/13). Thus, in addition to ease of access for harvesting, important plants are tended in gardens to defend them against pests more easily. 


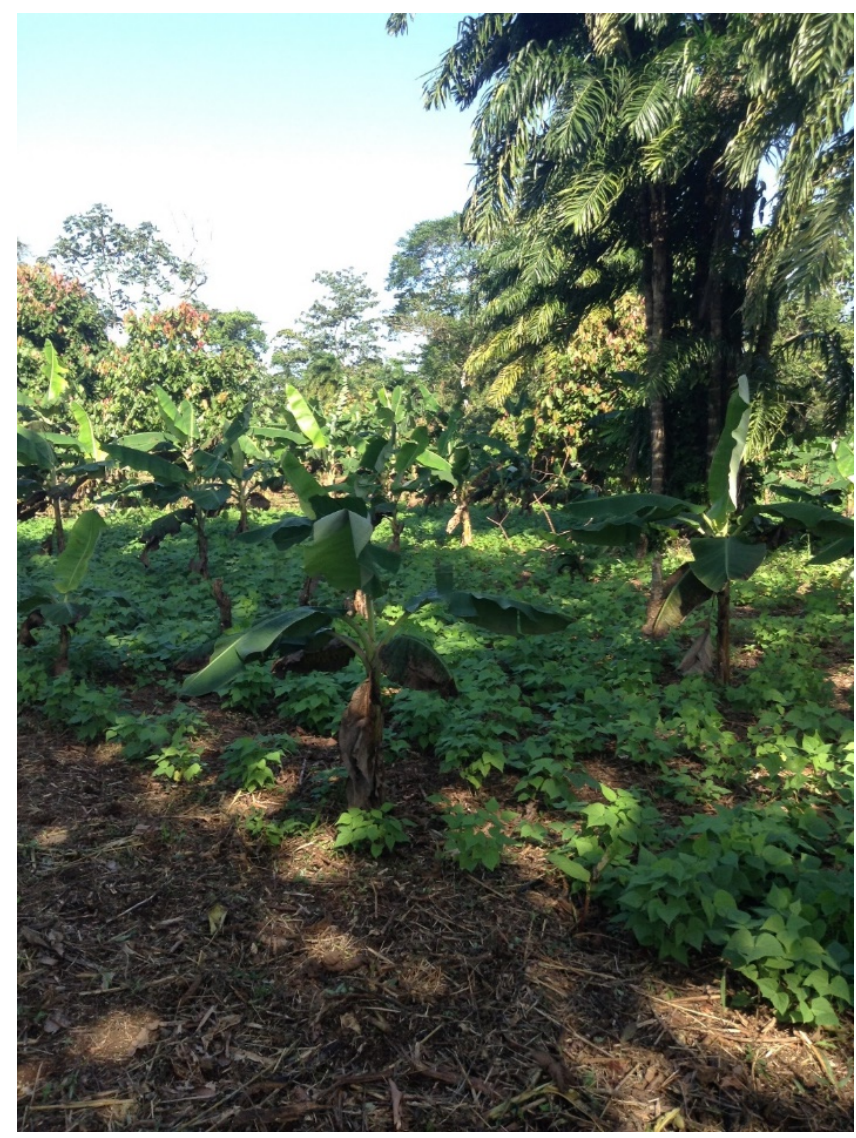

Figure 4: The agroforestry system of a farmer from Pearl Lagoon. Author's image.

Older farmers also have developed and acquired agroecological knowledge over the course of their lives in the region's agroecological milieu. This knowledge is most obvious when considering wild plant identification and application, inter-cropping configurations, and the use of in-situ decomposition to increase soil nutrients and productivity. Fire is utilized for initial clearing of areas by almost all farmers, however, key informants throughout the Basin reported re-planting fields for years or even decades in lieu of burning additional land. One farmer in Orinoco explained, "For cassava I chop it, let it rot and turn to manure. Then I use the area again" (interview 4/8/14). While burning provides a release of nutrients to the soil and is common in Central American tropical agricultural systems (Atran 1993), it is has unintended consequences. As summarized by a La Fe farmer, "[Burning] kill out everything. It burn the swamps and kill out all of the frogs and snakes and small animals" (interview 4/10/14).

Many informants perceive fauna as important components of agroecological systems, and farms often are configured to maintain a heterogeneous landscape for the benefit of certain fauna. A Pearl Lagoon farmer reported desiring a "little [forest], so no peal the whole farm." He believes that the small patch of forest "gives food to the monkeys, them" and "bring the birds," which this farmer sees as important attributes of a healthy agroecological system (interview 1/20/14). A farmer in Orinoco reinforced this sentiment, pointing to the aesthetic qualities of a "healthy" farm: "You no have area in reserve, you no have animals. I no want no big [pasture], it will destroy the beauty that I can have on the farm. I will lose the birds and the animals" (interview 4/8/14). The perceived danger of top predators and venomous species, such as jaguars and snakes, outweighs their aesthetic benefits, and often they are hunted, while most insects are seen as insurmountable 
pests. Therefore, only certain fauna, including animals hunted for food, such as ruminants, armadillos, and large rodents, fit into the local view of a healthy agroecological system and reserve areas serve as feeding grounds for these animals, helping to avoid crop loss.

As farmers age, they aim to develop low maintenance farming systems that produce a variety of subsistence resources, like food and medicine. Many, particularly older farmers, still rely on wild plants to meet their subsistence needs, therefore in addition to faunal habitat, reserve areas serve as easy-to-access procurement zones. Farmers also employ the agroecological knowledge developed over their lifetime, such as specific intercropping patterns that work in the various topologically distinct parts of their farm. A Kakabila farmer explained, "We plant dasheen down there," he pointed to a depression in his field, "but no corn, no pine[apple] neither, " as too much water will "kill them out" (interview 2/5/14). In contrast, young farmers are still developing their knowledge and often are just beginning to develop their farms in anticipation of the future, while they divide their time between farming and more financially lucrative livelihood activities. As a 20 year old Kakabila farmer stated, "I'm trying to build my little plantation" for the future, but right now he "catches every type of fish [he] can" to make money that he puts towards building his house in town (interview 10/6/13).

\section{Ethnicity-based rights, community, and agricultural development organizations}

In addition to age and experience, qualitative data reveals connections between other factors identified as significant predictors of agrobiodiversity, i.e. farmer ethnicity, community of residence, and interaction(s) with the regional agricultural development agencies. Locally-operating agricultural organizations seek to impact farmers' land use practices in ways that increase or bolster existing agrobiodiversity and focus on 'sustainable' agriculture as a means of strengthening local political-economic autonomy. As a local director of FADCANIC explained, "There needed to be an NGO that had resources to help the autonomy process. You can't have autonomy without development, and FADCANIC was going to direct development responsibly" (interview 12/17/13). Agroforestry is a fundamental part of that mission. As FADCANIC's website states, their effort to encourage "sustainable agroforestry systems" will "improve local livelihoods and conserve natural resources" (FADCANIC 2014).

In addition to educational extension, these organizations provide material resources (i.e. seeds or seedlings) to local farmers. These resources, however, are not distributed to everyone in the Basin, often resulting in intra-community tension. Each organization employs a slightly different process and/or criteria to select farmers to include in their projects. NicaCaribe, for example, asked community leaders to identify the 'farmers' in their community to receive plants, resulting in the potential for politicking. As one community leader and farmer explained, "I may know a man no farm, but I feel pressure to say him is" (interview 12/18/13). FADCANIC, BICU, and Black Farmers select farmers based on their community-level knowledge, seeking out individuals they believe will follow through with their projects (interviews 10/11/13 and 12/10/13). FADCANIC, for example, uses the results of previous project to select beneficiaries for future initiatives, thereby creating lineages of individuals who receive their resources (interview 9/1/13).

Communities also are not regarded equally by these organizations. Farmers from the town of Pearl Lagoon (who farm in Rocky Point), for example, are the primary beneficiaries of FADCANIC's extension efforts. In addition to ease of access (it abuts the road), FADCANIC administrators stress the importance of the historically agrobiodiverse farming practices characteristic of the older farmers in Rocky Point. As a local official clarified, "in Kakabila, for example, their way of being is to plant and eat cassava. The rest of their food comes from community fruit trees and the lagoon. Rocky Point has a different farming tradition. It is the fruit basket of the Atlantic Coast... nowhere else do afro-descendants plant in this way--with agroforestry" (interview 12/17/13). Because FADCANIC seeks to increase and conserve regional agrobiodiversity, these farmers are positioned to be the most amenable to FADCANICs activities. Therefore, although FADCANIC works around the Basin, Pearl Lagoon farmers receive its support disproportionately. 
Because FADCANIC and Black Farmers specifically aim to strengthen regional political-economic autonomy through their activities, ethnicity becomes an important attribute in the farmer selection process. For example, despite the heterogeneity of ethnic identities within communities around the lagoon, The Black Famers Cooperative exclusively works in communities described locally as Creole or Garifuna: which include Pearl Lagoon, Brown Bank, La Fe, and Orinoco. Within these communities, individuals are not barred from participation based on their identities. However, there is a relationship between the ethnicity assigned to a community and the proportion of community members that identify with that ethnicity. The Basin's settlement history resulted in people with shared histories (and ethnicities) tending to reside in specific communities. While most individuals-particularly in indigenous and afro-descendant communities-identify with multiple ethnicities, maintaining at least part of one's identity to correspond with that of the community identity (linking one to the community's history) is an important in the socio-politics of group membership, which helps secure community land access (a decision of community leaders). Therefore, most members of the Black Farmer Cooperative identify as Creole and/or Garifuna.

A member of the Black Farmers Cooperative in Orinoco (a Garifuna community) provides an apt example of the importance of ethnicity and the plasticity of identity in regards to community membership and resource access. During the agricultural survey, we spoke about his family history, he described his "mestiza mother" who was "from the Pacific" but lived in Pueblo Nuevo and his "Creole father" who was from Pearl Lagoon. The informant was raised along the river between Pueblo Nuevo (a mestizo community) and Orinoco, attending a missionary school and helping on the family farm. When asked about his ethnicity, I provided him a list of options with which he could say "yes" or "no" as to whether or not he identifies with this group. Miskito-"no", Creole—-"no", Garífuna—"I am a lone Garífuna man", Mestizo — -I told you, I am a lone Garífuna man" (interview 8/23/13). Without "being" Garífuna (of which he does not claim any hereditary link), this farmer would not have legitimate access to Orinoco community land. If he was unable to work Orinoco community land, it would be difficult (if not impossible) for him to gain membership in the Black Farmers Cooperative. Therefore, despite not being part of a Garifuna lineage, this farmer maintains a steadfast affiliation with this important sociopolitical category.

Aside from FADCANIC's credit program, farmers in mestizo-dominated Pueblo Nuevo receive little benefit from regional organizations. There, the majority of residents are recent migrants from Nicaragua's highland departments, including Boaco, Matagalpa, and Chontales, which are known for ranching. Interviews revealed that some migrants were landless in the Highlands, and many remain so in the Basin and work as laborers and tenants. In contrast, other recently migrated Pueblo Nuevo farmers sold parcels in the Highlands and used the profits to purchase land in the Basin. A life-long Pueblo Nuevo resident said of the newcomers, "the people come here because the land is cheap. They can sell their land in Chontales and buy twice as much here... In Chontales, there is only pasture, and they can't see the land in any other way. The land is for cows and horses. Nothing more" (interview 4/22/14). Local parcels are purchased either from other mestizo migrants or from residents of Tasbapauni, a coastal community on the north of the lagoon that historically farmed the area Pueblo Nuevo now occupies. These farms and ranches are the primary focus of household economies for families in Pueblo Nuevo.

Pueblo Nuevo's mestizo households are not included within the ethnic-based land rights that characterize autonomy in the Pearl Lagoon Territory. Therefore, they are not sought out as beneficiaries of agricultural extension projects led by FADCANIC, NicaCribe, The Black Farmers Cooperative, or BICU. Despite being exempt from resource distribution projects, however, relationships exist between some farmers in Pueblo Nuevo and agricultural development organizations, particularly FADCANIC. The Wawashang Agroforestry Centre is located on the bank of the Wawashang River, opposite Pueblo Nuevo. The close proximity provides easy access for local farmers to purchase seedlings and seeds from the Centre. Additionally, the Agroforestry Centre is almost exclusively staffed by Pueblo Nuevo residents. This includes long-term residents, migrants seeking wage labor, and agroforestry specialists who FADCANIC recruited to the region. Thus, while not targeting these non-afro-indigenous populations, FADCANIC's activities near 
Pueblo Nuevo appear to be disseminating knowledge of agroforestry techniques to locals hired to carry out these practices in the experimental farm and nursery.

\section{Discussion}

Quantitative and qualitative analyses revealed that a confluence of elements works to shape the ethnically-distinct patterns of land use characteristic of the Pearl Lagoon Basin-findings which affirm, augment, and challenge the findings of previous agrobiodiversity research. For example, this study supports theories that 'indigenous people' or ethnic minorities tend to have higher levels of plant diversity than their non-indigenous or non-minority neighbors (Brush and Perales 2007, Coomes and Ban 2004, PerraultArchambault and Coomes 2008, Perreault 2005). Additionally, this work confirms the importance of homegardens for species conservation (Aguilar-Støen et al. 2008, Coomes and Ban 2004, Lamont et al. 1999, Major et al. 2005, Perrault-Archambault and Coomes 2008, Trinh et al. 2003).

In contrast to previous work regarding the impacts of road development and increased connectivity on land use decision-making and agrobiodiversity conservation (Abbott 2005, Dusen and Taylor 2003, Major et al. 2005, Nazarea 2005), the political ecological approach employed in this study revealed that the most connected farmers in the Pearl Lagoon Basin - those who live closest to the road and participate in agricultural development projects-maintain the highest levels of agrobiodiversity. This phenomenon can be attributed in part to shifts in the underlying philosophies that drive agricultural development projects.

Agricultural development initiatives across Latin America have been shown to negatively affect agrobiodiversity conservation and disrupted sustainable land use practices (Abbott 2005, Conroy et al. 1996, Keleman et al. 2009, Stonich 1993, Thrupp 2000). However, development initiatives in the Pearl Lagoon Basin are working, directly and indirectly, to promote agrobiodiversity maintenance. Focused on the region's indigenous and afro-descendant communities, these initiatives incorporate contemporary concepts of ecosystem resilience and food security, stressing the importance of agrobiodiversity in building sustainable regional food systems (Brussaard et al. 2010, Harvey et al. 2008, Jackson et al. 2007, Thrupp 2000). Therefore, such organizations and activities not only provide evidence for evolution in the policies that guide Latin American agricultural development projects, but also they are key to understanding the relationship between ethnicity and agrobiodiversity in Nicaragua's Pearl Lagoon Basin and, potentially, in other regions of the world.

Ultimately, land use decisions in Nicaragua's Pearl Lagoon Basin are shaped by the histories of populations, agroecological knowledge passed through generations and accrued over farmers' lives, and the role of agriculture within their livelihood strategies. Examining ethnicity not simply as a predetermined characteristic, but as an active socio-political process, reveals the confluence of processes that shape the Basin's ethnically-distant agrobiodiversity maintenance patterns and highlights the complex interrelationships between ethnicity, community membership, ethnic-based land rights, and agricultural development organizations. Within the Basin's highly plastic ethnic landscape, individuals exercise specific configurations of identities to acknowledge their familial heritage, but also to secure community membership. This membership enables them to benefit from ethnic-based community land rights and places them in position to potentially benefit from the agricultural development projects that promote agrobiodiverse farming practices. Further, these projects aim to aid the very populations who historically maintained highly diverse agroforestry systems. Therefore, by affecting access to ethnic-based land rights and agricultural assistance programs, ethnicity shapes and is shaped by a farmer's maintenance of agrobiodiversity.

\section{Significance}

These findings are relevant to theory and to policy. First, by elucidating the mechanisms by which ethnic identity encourages agrobiodiverse cultivation strategies in the wake of road development, this study makes unique contributions to agrobiodiversity and land use literature. Further, its integrative political ecology framework has implications for other research aiming to account for the interactions and feedbacks between multi-level sociopolitical processes, which are key to understanding the reciprocal relationships that 
characterize socio-ecological systems (Biersack and Greenberg 2006, Brondizio et al. 2009, Bryant 1998, Caldas et al. 2015, Ostrom 2009, Paulson and Gezon 2005, Paulson et al. 2003, Young et al. 2006). My work shows how politics operating at various scales-from intra-community dynamics to changes in international development philosophies - shape ethnicity-agrobiodiversity relationships at the local-level and how ethnically-explicit policies regarding land and resources access based on these perceived patterns in turn shape individuals' identities. Therefore, the quantitative-qualitative research framework I employed enabled the tracking of power relationships from the global to the local, the identification of how these relationships shape human-environmental relationships, and the elucidation of how people navigate multi-scaled power structures to gain access to the resources they need to survive, ultimately reinforcing the importance of complex, multi-level sociopolitical processes in shaping human-environmental systems (Paulson and Gezon 2005).

Finally, in elucidating the links between ethnicity and land use patterns, my research demonstrated how contemporary development politics focuses on historically marginalized indigenous and 'ethnic minority' populations as the stewards of agrobiodiversity, and tries to enhance their abilities to remain resilient to agrobiodiversity erosion in the face of global change. Yet, it is critical for development agencies working in Caribbean Nicaragua to acknowledge that those individuals most likely to engage in land use practices that obstruct region development goals (i.e. newly migrated mestizos) are the least likely to benefit from projects seeking to improve agrobiodiversity and forest conservation. Beneficiaries tend to be those who traditionally maintained high levels of agrobiodiversity. The populations who could benefit the most from outreach efforts lack legal rights to the land that they are transforming. In order to secure the long-term viability of local natural resources (and livelihoods), policy-makers must recognize this inconvenient reality and implement policies that target these groups.

\section{Bibliography}

Abbott, J.A. 2005. Counting beans: agrobiodiversity, indigeneity, and agrarian reform. The Professional Geographer 57(2): 198-212.

Aguilar-Støen, M., S.R. Moe, and S.L. Camargo-Ricalde. 2008. Home gardens sustain crop diversity and improve farm resilience in Candelaria Loxicha, Oaxaca, Mexico. Human Ecology 37(1): 55-77.

Anderson, J.L. 2015. Breaking ground on the Nicaragua canal. The New Yorker. January 2.

Armah, R.N.A., R.M. Al-hassan, J.K.M. Kuwornu and Y. Osei-Owuso. 2013. What influences farmers' choice of indigenous adaptation strategies for agrobiodiversity loss in northern Ghana? British Journal of Applied Science and Technology 3(4): 1162-1176.

Atran, S. 1993. Itza Maya tropical agro-forestry. Current Anthropology 34(5): 633-700.

Baco, M.N., G. Biaou and J.-P. Lescure. 2007. Complementarity between geographical and social patterns in the preservation of yam (Dioscorea sp.) diversity in northern Benin. Economic Botany 61(4): 385-393.

Barth, F. 1969. Ethnic groups and boundaries: the social organization of culture difference. Long Grove: Waveland.

Beals, M., L. Gross and S. Harrell. 2000. Diversity indices: Shannon's H and E. http://www.tiem.utk.edu/ gross/bioed/bealsmodules/shannonDI.html

Beer, G. and S. Vanegas. 2007. Diagnóstico para la demarcación de las doce comunidades indígenas y afrodescendientes de la cuenca de Pearl Lagoon. Bluefields.

Bellon, M. 2004. Conceptualizing interventions to support on-Farm genetic resource conservation. World Development 32(1): 159-172.

Bernard, H.R. 2006. Research methods in anthropology: qualitative and quantitative approaches. Lenham: Altamira.

BICU. 2015. Bluefields Indian and Caribbean University. http://www.bicu.edu.ni.

Biersack, A. and J.B. Greenberg. 2006. Reimagining political ecology: new ecologies for the twenty-first century. Durham: Duke University Press. 
Brondizio, E.S., E. Ostrom and O.R. Young. 2009. Connectivity and the governance of multilevel socialecological systems: the role of social capital. Annual Review of Environment and Resources 34:253278.

Brunnegger, S. 2007. From conflict to autonomy in Nicaragua: lessons learnt. Minority Rights Group International.

Brush, S.B. 2004. Cultural research on the origin and maintenance of agricultural diversity. In O. Sanga, G. Sanga, and G. Ortalli (eds.) Nature knowledge: ethnoscience, cognition, and utility. Brooklyn: Berghahn Books.

Brush, S.B. and H.R. Perales. 2007. A maize landscape: ethnicity and agro-biodiversity in Chiapas Mexico. Agriculture, Ecosystems and Environment 121(3): 211-221.

Brussaard, L., P. Caron, B. Campbell, L. Lipper, S. Mainka, R. Rabbinge, D. Babin and M. Pulleman. 2010. Reconciling biodiversity conservation and food security: scientific challenges for a new agriculture. Current Opinion in Environmental Sustainability 2(1-2): 34-42.

Bryant, R.L. 1998. Power, knowledge and political ecology in the third world: a review. Progress in Physical Geography 22(1): 79-94.

Caldas, M.M., M.R. Sanderson, M. Mather, M.D. Daniels, J.S. Bergtold, J. Aistrup, J.L. Heier Stamm, D. Haukos, K. Douglas-Mankin, A.Y. Sheshukov and D. Lopez-Carr. 2015. Opinion: endogenizing culture in sustainability science research and policy. Proceedings of the National Academy of Sciences of the United States of America 112(27): 8157-8159.

Carr, D.L. 2008. Farm households and land use in a core conservation zone of the Maya Biosphere Reserve, Guatemala. Human Ecology 36(2): 231-248.

Coe, F.G. 2008. Ethnobotany of the Rama of southeastern Nicaragua and comparisons with Miskitu plant lore. Economic Botany 62(1): 40-59.

Coe, F.G. and G.J. Anderson. 1996. Ethnobotany of the Garífuna of eastern Nicaragua. Economic Botany 50(1): 71-107.

Coe, F.G. and G.J. Anderson. 1997. Ethnobotany of the Miskitu of eastern Nicaragua. Journal of Ethnobiology 17(2): 171-214.

Conroy, M.E., D.L. Murray, and P.M. Rosset. 1996. A cautionary tale: failed U.S. development policy in Central America. London: Lynne Rienner.

Conservation International. 2014. Hotspots - Conservation International. http://www.conservation.org/How/Pages/Hotspots.aspx

Coomes, O.T. and N. Ban. 2004. Cultivated plant species diversity in home gardens of an amazonian peasant village in northeastern Peru. Economic Botany 58(3): 420 - 434.

Coomes, O.T. and G.J. Burt. 1997. Indigenous market-oriented agroforestry: dissecting local diversity in western Amazonia. Agroforestry Systems 37(1): 27-44.

Van Dusen, E. and J.E. Taylor. 2005. Missing markets and crop diversity: evidence from Mexico. Environment and Development Economics 10:513-531.

Ellen, R.F., P. Parkes and A. Bicker. 2000. Indigenous environmental knowledge and its transformations: critical anthropological perspectives. Hove: Psychology Press.

Eriksen, T.H. 2002. Ethnicity and nationalism. London: Pluto Press.

Escobar, A. 2008. Territories of difference: place, movements, life, redes. Durham: Duke University Press. Spanish

FADCANIC. 2014. Development of the Atlantic Coast of Nicaragua. http://www.fadcanic.org.ni

Garí, J.A. 1999. Biodiversity and indigenous agroecology in Amazonia: the indigenous peoples of Pastaza. Etnoecológica 5(7): 21-37.

Geertz, C. 1973. The interpretation of cultures: selected essays. New York: Basic Books.

Godoy, R., V. Reyes-García, E. Byron, W. R. Leonard, and V. Vadez. 2005. The effect of market economies 
on the well-being of indigenous peoples and on their use of renewable natural resources. Annual Review of Anthropology 34(1): 121-138.

Goett, J.A. 2006. Diasporic identities, autochthonous rights: race, gender, and the cultural politics of Creole land rights in Nicaragua. Ph.D. dissertation. Austin: University of Texas - Austin.

Gotelli, N.J. and R.K. Colwell. 2001. Quantifying biodiversity: procedures and pitfalls in the measurement and comparison of species richness. Ecology Letters 4(4): 379-391.

Gould, J.L. 1998. "¡Vana Ilusión!" The highlands indians and the myth of Nicaraguan Mestiza, 1880-1925. In A. Chomsky and A. Lauria-Santiago (eds.) Identity and struggle at the margins of the nation-state: the laboring peoples of Central America and the Hispanic Caribbean. Durham: Duke University Press.

Hale, C.R. 1994. Resistance and contradiction: Miskitu indians and the Nicaraguan state, 1894-1987. Palo Alto: Stanford University Press.

Hale, C.R. 2006. Mas que un indio. Santa Fe: School for Advanced Research Press.

Harvey, C., O. Komar, R. Chazdon, B.G. Ferguson, B. Finegan, D.M. Griffith, M. Martínez-Ramos, H. Morales, R. Nigh, L. Soto-Pinto, M. Van Breugel and M. Wishnie. 2008. Integrating agricultural landscapes with biodiversity conservation in the Mesoamerican hotspot. Conservation Biology: the journal of the Society for Conservation Biology 22(1): 8-15.

Helms, M.W. 1969. The purchase society: adaptation to economic frontiers. Anthropological Quarterly 42(4): 325-342.

Helms, M.W. 1971. Asang adaptations to culture contact in a Miskito Community. Gainesville: University of Florida Press.

Huang, R. 2014. RQDA: R-based qualitative data analysis.

IFC. 2010. Cukra palm oil: summary of proposed investment.Washington DC: International Finance Corporation.

INTA. 2015. Instituto Nicaragüense de Tecnología Agropecuaria. http://www.inta.gob.ni

Jackson, L., U. Pascual, and T. Hodgkin. 2007. Utilizing and conserving agrobiodiversity in agricultural landscapes. Agriculture, Ecosystems and Environment 121(3): 196-210.

Jamieson, M. 1999. Poverty among the indigenous peoples of Atlantic Nicaragua. Indigenous Peoples and Community Development Unit, Inter-American Development Bank, Sustainable Development Dept.

Jamieson, M. 2003. Miskitu or Creole? ethnic identity and the moral economy in a nicaraguan miskitu village. Journal of the Royal Anthropological Institute 9(2): 201-222.

Keleman, A., J. Hellin, and M.R. Bellon. 2009. Maize diversity, rural development policy, and farmers' practices: lessons from Chiapas, Mexico. Geographical Journal 175(1): 52-70.

Kirby, K.R. 2011. Relative influence of cultural identity and market access on agricultural biodiversity in swidden-fallow landscapes of eastern Panama. Ph.D. dissertation. The University of British Columbia.

Lamont, S.R., W.H. Eshbaugh, and A.M. Greenberg. 1999. Species composition, diversity, and use of homegardens among three Amazonian villages. Economic Botany 53(3): 312-326.

Major, J., C.R. Clement, and A. DiTommaso. 2005. Influence of market orientation on food plant diversity of farms located on amazonian dark earth in the region of Manaus, Amazonas, Brazil. Economic Botany 59(1): 77-86.

Martínez, M., S. León, and J. Garth. 2007. Pendientes las carreteras al Caribe. La Prensa. 15 January.

McNeely, J.A., and S.J. Scherr. 2003. Ecoagriculture: strategies to feed the world and save wild biodiversity. Washington, DC: Island Press.

Mi Familia. 2015. Ministerio de la Familia Adolecencia y Ninos. http://www.mifamilia.gob.ni

Michaud, J., and T.J. Forsyth (eds.) 2011. Moving mountains: ethnicity and livelihoods in highland China, Vietnam, and Laos. Vancouver: UBC Press. Introduction

Nazarea, V.D. 2005. Heirloom seeds and their keepers: marginality and memory in the conservation of biological diversity. Tucson: University of Arizona Press. 
Nazarea, V.D. 2006. Local knowledge and memory in biodiversity conservation. Annual Review of Anthropology 35: 317-335.

Nietschmann, B. 1973. Between land and water. New York: Seminar Press.

Orlove, B.S. and S.B. Brush. 1996. Anthropology and the conservation of biodiversity. Annual Review of Anthropology 25: 329-352.

Ostrom, E. 2009. A general framework for analyzing sustainability of social-ecological systems. Science 325(5939): 419-422.

Paulson, S. and L.L. Gezon. 2005. Power, place, difference: multiscale research at the dawn of the twentyfirst Century. In S. Paulson, and L.L. Gezon (eds.) Political ecology across spaces, scales, and social groups. New Brunswick: Rutgers University Press.

Paulson, S., L.L. Gezon and M.J. Watts. 2003. Locating the political in political ecology: an introduction. Human Organization 62(3): 205-217.

Perrault-Archambault, M. and O.T. Coomes. 2008. Distribution of agrobiodiversity in home gardens along the Corrientes river, Peruvian Amazon. Economic Botany 62(2): 109-126.

Perreault, T. 2005. Why chacras (swidden gardens) persist: agrobiodiversity, food security, and cultural identity in the Ecuadorian Amazon. Human Organization 64(4): 327-339.

Pineda, B.L. 2006. Shipwrecked identities: navigating race on Nicaragua's Mosquito Coast. New Brunswick: Rutgers University Press.

Postero, N.G. 2006. Now we are citizens: indigenous politics in postmulticultural Bolivia. Palo Alto: Stanford University Press.

R Core Team. 2013. R: A language and environment for statistical computing. R Foundation for Statistical Computing, Vienna, Austria. http://www.R-project.org

Saldivar, E. 2011. Everyday practices of indigenismo: an ethnography of anthropology and the Mexican state. The Journal of Latin American and Caribbean Anthropology 16(1): 67-89.

Speed, S. 2007. Rights in rebellion: indigenous struggle and human rights in Chiapas. Palo Alto: Stanford University Press.

Stevens, K., B. Irwin, D. Kramer, and G. Urquhart. 2014. Impact of increasing market access on a tropical small-scale fishery. Marine Policy 50: 46-52.

Stonich, S.C. 1993. I am destroying the land: the political ecology of poverty and environmental destruction in Honduras. Boulder: Westview Press.

Thrupp, L.A. 2000. Linking agricultural biodiversity and food security: the valuable role of sustainable agriculture. International Affairs 76(2): 265-281.

Trinh, L.N., J.W. Watson, N.N. Hue, N.N. De, N.V. Minh, P. Chu, B.R. Sthapit and P.B. Eyzaguirre. 2003. Agrobiodiversity conservation and development in Vietnamese home gardens. Agriculture, Ecosystems and Environment 97(1-3): 317-344.

Veteto, J.R. and K. Skarbø. 2009. Sowing the seeds: anthropological contributions to agrobiodiversity studies. Culture and Agriculture 31(2): 73-87.

Vincent, J. 1974. The structure of ethnicity. Human Organization 33(4): 375-379.

Wezel, A. and J. Ohl. 2005. Does remoteness from urban centres influence plant diversity in homegardens and swidden fields? A case study from the Matsiguenka in the Amazonian rain forest of Peru. Agroforestry Systems 65(3): 241-251.

Wimmer, A. 2013. Ethnic boundary making: institutions, power, networks. New York: Oxford University Press.

Young, O., F. Berkhout, G. Gallopin, M. Janssen, E. Ostrom and S. Vanderleeuw. 2006. The globalization of socio-ecological systems: an agenda for scientific research. Global Environmental Change 16(3): 304316.

Zimmerer, K.S. 2004. Cultural ecology: placing households in human-environment studies - the cases of 
tropical forest transitions and agrobiodiversity change. Progress in Human Geography 28(6): 795-806.

Zimmerer, K.S. 2010. Biological diversity in agriculture and global change. Annual Review of Environment and Resources 35(1): 137-166.

Zimmerer, K.S. 2015. Environmental governance through "speaking like an indigenous state" and respatializing resources: ethical livelihood concepts in Bolivia as versatility or verisimilitude? Geoforum 64: 314-324. 